\title{
Reading Translational
} Semiotics Hermeneutically: Juri Lotman's Kyльmypa и взрыв and Wilma Clark's Culture and Explosion Imagined Icotically as a Single Translingual Text

\begin{abstract}
Juri Lotman offers an intriguing "two-language" principle for the study of signs, which effectively requires translation as a disruption of the unificatory regimes of individual semiospheres; and yet, problematically, he doesn't channel his own theorizing of the semiosphere through translation, with the result that his theorizing tends to gravitate toward truth-telling, and so toward unification and stabilization. This article both argues for a stereoscopic reading of Lotman's Культура и взрьєв ('Kul'tura i zryv') and Wilma Clark's English translation Culture and Explosion, as a second-best application of the two-language principle to Lotman's cultural semeiotic, and illustrates some of the consequences for the semiotic study of such a reading.
\end{abstract}

Keywords: translation, hermeneutics, semiosphere, culture, explosion, dissipative system, stereoscopic reading, translinguality.

Juri Lotman (1922-1993), the Russian "cultural semiotician" of the Tartu-Moscow School, famously insisted that not only the study but the very existence of what he called the семиосфера 'semiosphere' required translation, or translational action, or what I have called "translationality" (Robinson 2017d), because the semiosphere is (self-)organized(/-ing) through management of its shifting boundary with the extra-semiotic, and the shifts and transfers across that boundary can best be identified through translation between or among two or more languages. Like Walter Benjamin (1923/1972, Rendall 1998), Lotman insists that translation mobilizes the differences among

1 For Lotman's publications on the semiosphere, see Lotman (1984)/Clark (2005) and Lotman (1996/2000: part 2)/ Shukman (1990: part 2). 
languages for transformative purposes; unlike Benjamin's, his interest in those transformations orients him not to some messianic future but to the ongoing (self-)structuring action of semiosis.

Or, as both he writes in his last book, Культура и взрьвв (1992/2000: 13), and Wilma Clark writes in her English translation, Culture and Explosion (2009: 2):

Одним из центральных вопросов окажется вопрос перевода мира содержания системы (ее внутренней реальности) на внележащую, запредельную для языка реальность. Следствием будут два частных вопроса:

1. необходимость более чем одного (минимально двух) языков для отражения запредельной реальности;

2. неизбежность того, что пространство реальности не охватывается ни одним языком в отдельности, а только их совокупностью.

Представление о возможности одного идеального языка какоптимального механизмадля выражения реальности является иллюзией. Минимальной работающейструктурой является наличиедвухязыков и их неспособность, каждого в отдельности, охватить внешний мир. Сама эта неспособность есть не недостаток, а условие существования, ибо именно она диктует необходимость другого (другой личности, другого языка, другой культуры). ... Языки эти как накладываются друг на друга, поразному отражая одно и то же, так и располагаются в <одной плоскости», образуя в ней внутренние границы. Их взаимная непереводимость (или ограниченная переводимость) является источником адекватности внеязыкового объекта его отражению в мире языков.

One of the key problems is that of the translation of the world of the content of the system (its internal reality) to the reality that lies outside, beyond the borders of language. Out of this, two specific issues arise:

1. The necessity that more than one language (a minimum of two) is required in order to reflect a given reality

2. The inevitable fact that the space of reality cannot be represented by a single language but only by an aggregate of languages.

The idea of the possibility for a single ideal language to serve as an optimal mechanism for the representation of reality is an illusion. A minimally functional structure requires the presence of at least two languages and their incapacity, each independently of the other, to embrace the world external to each of them. This incapacity is not a deficiency, but rather a condition of existence, as it dictates the necessity of the other (another person, another language, another culture).... These languages superimpose themselves on each other in such a way as to reflect one and the same thing in different ways, so that they appear to be situated on a "single plane" and form its internal borders. Their mutual untranslatability (or limited translatability) represents a source of adjustment of the extra-lingual object in its reflection in the world of languages.

What I want to argue in this paper is that, excellent as Lotman's two-languages principle is in theory, it would have been even more powerful had he enacted it, by presenting his theoretical work 
simultaneously in Russian and English translation. Instead, by relying exclusively on his native Russian, he is often lured into a lecturing "truth-telling" mode that frequently seems to imply precisely what he rejects here, that it is possible to represent the world monolingually without slippage.

Here, for example, is one of his incisive observations, from later in the book, of the inevitable slippage within semiosis: “полностью стабильных, неизменяющихся семиотических структур, видимо, не существует вообще" (102). The overriding idea there is that "Completely stable invariant semiotic structures do not exist at all"-there is at least the possibility of slippage everywhere-but even that account of inevitable instability is too stable an ontological claim. He hedges, therefore, with видимо, an adverb derived from the verb for "to see" and typically translated "apparently" or "it would appear," implying something like "I can't be totally sure I'm right here." Even the claim that total stability is impossible, in other words, has to be destabilized.

And yet, somehow, even that destabilizing hedge contributes to the ontological stability of the claim. Why? Because, as he himself specifically insists will always happen, the single language in which he writes it is inadequate to the destabilization that he seeks to theorize.

So now let us add Wilma Clark's translation of the sentence: "Completely stable invariant semiotic structures do not exist at all, generally speaking” (115). The kneejerk move, there, which I want to problematize, would be to chide Clark for mistranslating видимо as "generally speaking." The trouble with "generally speaking" is that it destabilizes the stable claim about inevitable instability in the "wrong" direction: it implies that sometimes completely stable invariant semiotic structures do exist. It's easy enough to complain, not only that видимо simply does not mean "generally speaking," but also that the translation error restabilizes rather than (as per Lotman) further destabilizing the destabilizing claim.

I would submit, however, that the very cognitive and affective dissonance between the two phrasings adds a complexity to Lotman's argument that he could not have generated monolingually. The semiotic complexity that he seeks to theorize does not exist in Russian, or in English, or in any other language. It exists-or rather, it emerges-in translation. It is an interlingual/ transsemiotic becoming.

Rather than doing the error analysis that still constitutes the normative methodological core of the TS equivalence paradigm, therefore, what I want to do in this paper is to shift a possible/ imagined discussion of "translation errors" to a higher level, by promoting a translingual/ stereoscopic "translational reading/writing" strategy that to my mind is the ideal hermeneutical context for understanding Lotman's semiospheric theory. If а “минимальной работающей [семиосферической] структурой является наличие двух языков и их неспособность, каждого в отдельности, охватить внешний мир”/“minimally functional [semiospheric] structure requires the presence of at least two languages and their incapacity, each independently of the other, to embrace the world external to each of them," and if this means that those languages' “взаимная непереводимость (или ограниченная переводимость) является источником адекватности внеязыкового объекта его отражению в мире языков”/“mutual untranslatability (or limited translatability) represents a source of adjustment of the extra-lingual object in its reflection in the 
world of languages," then, arguably, Lotman's model cannot function minimally in a single language like Russian-or, for that matter, Clark's English. We need both, hermeneutically intertwined. And I want to argue that it is precisely the problems in Clark's translation of Lotman that make it the "perfect" (if that's the right word here!) translingual companion-text to Lotman's Russian.

\section{The Binary Logic of Explosion}

For convenience, I will limit my discussion to a single chapter in the book, which is numbered 11 in Clark's translation: “Логика взрыва” in Russian, “The Logic of Explosion” in English. Lotman begins there by distinguishing between the standard "представление о тексте как пересечении точек зрения создателя текста и аудитории” (103)/“concept of the text as the intersection of the point of view of the author of the text and the audience" (116), which, he notes, forms an irreducible clash that in most discussions of text is improperly reduced:

Так, с позиции автора, текст может выступать как незаконченный, находящийся в динамическом состоянии, в то время как внешняя точка зрения (читателя, издателя, редактора) будет стремиться приписывать тексту законченность. (103)

Thus, from the position of the author, the text may appear to be unfinished, to be situated in a dynamic state, whilst the external point of view (reader, publisher, editor) will attempt to assign to the text a state of completion. (116)

Out of this initial binary Lotman then goes on to develop a derivative binary between "the world of proper names," where everything is intimately known and cherished as "one's own," and "the world of proper nouns," where everything is abstract and pure, a stable transcendental realm far from the phenomenological world experienced by living creatures in their bodies and time. The former, obviously, is akin to the author's perspective on "the text" as an emergence, a dynamic creativity characterized by unpredictable "explosions" (his chaos-theoretical theme in the book); the latter is akin to the publisher's and reader's perspective on "the text" as a fixed entity with stable characteristics.

And then, out of that derivative binary, Lotman develops a third binary between fictional plots that are multiple, unstable, fluctuatingly and therefore endlessly open to divergent interpretations, and fictional plots (for example, whodunits) that are like riddles, so that, once the identity of the killer has been learned, they are forever exhausted.

At this point, however, he begins mapping out salutary middles between binary extremes, and showing how even the most apparently stable plots contain a "dissipative" structure, a vulnerability to unpredictable symmetry-breaking events. The detective stories of Edgar Allan Poe, for example, seem to belong to the latter group-riddles with once-off solutions-but in fact complicate that apparent generic plot with fantastic complications that are irresolvable; and novels like G. K. Chesterton's The Man Who Was Thursday, while so delightfully complex in their plot structures 
as to be rereadable with pleasure, are actually riddles that are contrary to art. Let's look first at one paragraph from his account of Chesterton:

Таким образом, Честертон как бы вводит нас в мир непредсказуемости и, следовательно, создает текст, подчиняющийся художественным законам. Однако на самом деле это не более чем гениально построенная мистификация. Подобно тому как любая задача имеет только одно правильное решение, а искусство аудитории состоит в том, чтобы это решение найти, честертоновский сюжет ведет нас к одной однозначной истине. Запутанные клубки сюжета призваны замаскировать этот путь, сделать его доступным лишь тому, кто владеет тайнами единственного решения.

Такая ситуация принципиально противоположна искусству, говорим ли мы о гениальных или посредственных его проявлениях. (107; emphasis added)

In this way, Chesterton seemingly introduces us to the world of unpredictability and, consequently, creates a text which is subjugated to artistic laws. However, in actual fact, this is no more than a brilliantly constructed mystification. As is the case when a task has only one correct solution and the art of the audience lies in finding this solution; the Chestertonian subject leads us to a singular truth. The intricate web of the plot lines is designed to disguise this way, making it accessible only to the reader who manages to unravel the secrets of the unique solution.

Such a situation is fundamentally opposed to art, whether we are speaking of its brilliant or its mediocre manifestations. (121; emphasis added)

The phrase I've italicized in both passages there, "на самом деле"/“in actual fact," is my main interest in this section: the apparent certainty with which Lotman overturns the "гениально построенная мистификация”/“brilliantly constructed mystification” and establishes the stable, even possibly transcendent, truth. More on this as we go along. Here is a similar claim from the opposite side of the binary, about Poe:

В этом смысле интересен пример повести Эдгара По. Читателю как бы подсказывается представление о том, что страшная загадка, которую предлагает ему автор, подразумевает одноединственное «правильное) решение, и композиция повести строится согласно устойчивой схеме: загадка, которую можно и нужно отгадать, погруженная в раму фантастических ужасов. ... На самом деле художественная сила творчества Э. По состоит именно в том, что он ставит перед читателями загадки, которые нельзя решить. Это не проблемы современности, упакованные в фантастические сюжетные фантики, а сама неразрешимая фантастика. Э. По открывает перед читателями путь, у которого нет конца, окно в непредсказуемый и лежащий по ту сторону логики и опыта мир. Его повести не подразумевают хитрой и однозначной сотгадки». (107-8; emphasis added)

In this regard, the example of the tales of Edgar Allan Poe is interesting. The reader seems implicitly to realise that the terrible riddle proposed by the author offers only one "correct" solution and the 
composition of the tale is constructed according to a stable schema: the riddle, which it is possible and necessary to solve, lies submerged in the frame of fantastic horrors. ... In actual fact, the artistic strength of the works of E.A. Poe consists precisely in the fact that he lays before the reader riddles which cannot be solved. These are not modern problems packed in the fantastic candy wrappers of plot but the fantastic itself that is insoluble. E. A. Poe opens before the reader a way without end, a window onto unpredictability, lying on the other side of logic and worldly experience. His tales do not imply any sly or simple "explanations." (121; emphasis added)

We could do the old error-analysis thing with that, and ask, for example, whether Эдгар По in one sentence and Э. По in later sentences should really be rendered first Edgar Allan Poe and then E. A. Poe (isn't Poe in English always either "Edgar Allan Poe" or "Poe"?), or whether "хитрый" in the last sentence is really "sly," which implies a negatively moralized deviousness that we do not normally project onto novelists (a better translation might be "clever[ly hidden]"). We could tsk our tongue at Wilma Clark's apparent ignorance of the difference between restrictive and non-restrictive subordinate clauses, when she translates "сама неразрешимая фантастика" restrictively as "the fantastic itself that is insoluble" (restricting the claim to only that kind of fantasy that is irresolvable) rather than non-restrictively as "the fantastic itself, which is insoluble" (meaning that all fantasy is unresolvable ${ }^{2}$ ). To the end of suggesting a more complexly useful approach to such "problems" below, I will return in section 2 to the syntactic slippage implicit in the translation of restrictive/non-restrictive modifiers in the context of an interlingual/ transsemiotic (translational) phenomenology.

Before he comes to Chesterton and Poe, also, Lotman devotes two and a half pages to tracing the artistic (viz., unpredictable) complexities of Charlie Chaplin's filmography, and is again at pains to establish the "actual fact" of the matter:

Вставной эпизод с танцующей куколкой, составленной из двух хлебцев, которую Чарли заставляет выполнять изысканные танцы и разнообразные движения, не имеет, казалось бы, прямого отношения к сюжету (он вставлен как забава, которой предается нищий герой, напрасно ожидая в гости кокетливую героиню). Однако на самом деле эпизод этот является ключом ко всему фильму. (105; emphasis added)

2 More error analysis: a mystery (which may or may not have a "решение"/"solution”) is (in)soluble or (un)solvable, but a plot (which may or may not have a "разрешение"/“resolution") is (ir)resoluble or (ir-/un)resolvable. Since "the fantastic" as a plot structure can't really have a resolution, it is by definition irresolvable. (And Lotman's adjective "неразрешимая" does have that "разрешение"/resolution" in it: morphologically, it is "irresolvable.") Of course, "the fantastic" isn't a mystery either-isn't a riddle with a solution-and so could arguably be by definition "insoluble." The higher hermeneutical level that I seek above error analysis would seek to accommodate and explore the "irresolvable" tensions between conflicting constructions of semantic and syntactic reference to real-world objects like plots and mysteries. Depending on whether we construct “неразрешимая" as "insoluble" or "unresolvable," wе are constructing “фантастика"/"the fantastic” as either a mystery/riddle or a plot/tension. More on this in section 2. 
The episode of the dancing doll, made up of two loaves, which Charlie causes to carry out refined dances and diverse movements do not, it would seem, have any direct relation to the subject (it was inserted for amusement, in which the poor hero who waits in vain for his guest, the coquettish heroine, is involved). However, in actual fact, this episode is the key to the entire film. (117; emphasis added)

In the normative spirit of error analysis, once again, we could point out there that Clark doesn't know the punctuation rule about closing a parenthetical item like "which Charlie causes to carry out refined dances and diverse movements" with a final comma (and tsk our tongues at the dogged insistence with which she keeps making that mistake throughout the book); and we could trumpet triumphantly that, as a result, she lets herself get confused as to the grammatical subject of the sentence: somehow she thinks that the sentence is "movements do not," when of course it is actually “эпизод не имеет”/“the episode does not."

But again, the point I want to stress is not Clark's carelessness as Lotman's English translator, but rather Lotman's carelessness as an exemplifier of his own theory: namely, his inclination to pronounce authoritatively, stably, objectively on what is really going on in these texts, with the telltale phrase "на самом деле”/“in actual fact." There is a fact; it is an actual fact (or, in Russian, a “самое дело"/“very deed, deed itself"); and, most telling of all, it is a linguistically decontextualized fact. Reading Chesterton and Poe, Lotman is engaging texts that were originally produced in English. Is he reading Chesterton and Poe in Russian translation, or in the original English? He doesn't bother to tell us. The "самое дело"/“actual fact" about those texts is a transcendental fact, serenely unaffected by the language, or the translation history, in which he has encountered the events that led him to postulate it. Most important, even if he's reading these texts in their "original" English, his own two-language model of the semiosphere should arguably require that each phenomenon be explored not as a stable univocal/monolingual "actual fact," but as a shifting mental construct abstracted out of-but remaining inexorably inflected and striated by-the transgressive/transsemiotic action of translation.

\section{The Translational Phenomenology of Explosion}

One might want to speculate that Lotman's main struggle throughout this book, and in some broad sense throughout his prolific academic career, is with the Platonic/Christian/scientific/academic discursive habits that make it "natural," the most "natural" thing in the world, to be transcendentally sure of one's binary claims-and that, like most of us, he is winning that struggle only in places, yielding to it in others. Chesterton seems to be an artist of unpredictability, but in actual fact he's no artist at all. Poe seems to be writing riddle-like whodunits, but in actual fact his fantastic elements brilliantly transgress that genre (in the act of inventing it). Chaplin's dancing doll would appear to be irrelevant to his plot, but in actual fact it's the key to the movie. You, the naïve reader, may think you understand these things, but you don't; I'm here to tell you the (surprising) truth. This discursive habit runs deep in academic and ecclesiastical tradition, and, 
despite its utter incongruity with Lotman's quite brilliant semiospheric theory, survives somewhat awkwardly in his argumentation here.

The hermeneutical lens that I bring to bear on Lotman's theory also makes me wonder whether the structuralist-or perhaps (post)structuralist-turn taken in the Tartu-Moscow School might be tempting Lotman to depersonalize his argument, and so leaving him vulnerable to the old rhetorical tic of transcendental certainty. The subtle sidelining of the Peircean "phaneroscopic" (phenomenological) impulse in the post-Peircean Eastern European semiotic tradition from Roman Jakobson to Juri Lotman tends to mean that, even when he invokes Ilya Prigogine's (1973; see Robinson unpub-b for discussion) dissipative systems to challenge the transcendentalization of stable structure, Lotman tends to see structures shifting rather than human beings experiencing semiosis as kinesthetic clashes and tensions.

And indeed this institutional inclination toward the depersonalization/structuralization of "truth" is a telling index of the ways in which, as Lotman's own two-language theory predicts, his theoretical argument falls short of its own goal, and would attain its fullest hermeneutical complexity only in translation. Lotman's (post)structuralist semeiotic is most at home exploring the binary logic of "culture and explosion," with cultural order on one side (cf. “на самом деле”/“in actual fact") and unpredictable chaotic "explosions" on the other; but his two-language theory of the semiosphere would seem to require, as his most pressing rhetorical exigency, a translational phenomenology of explosion-a hermeneutic of people living between languages, experiencing the explosive surprises and tensions that arise out of overlapping referential divergences.

Such a phenomenology, I suggest, would be a dissipative system of felt transgressive tensionsacross-boundaries in which the symmetry-breaking events that Lotman calls explosions are experienced hermeneutically as unexpected incursions from the extra-semiotic realm into the semiosphere. And to the extent that Lotman himself experienced those incursions, I suggest-and of course he did, not only as a practicing translator but as a multilingual Jewish intellectual living outside anti-Semitic Soviet Russia-he could also have situated his readers hermeneutically in that uncomfortable Schleiermacherian place, "haltungslos in unerfreulicher Mitte" (Schleiermacher 1813/2002: 87)/“disoriented in the unpleasant middle” (Robinson 1997/2002: 235). And he could cue that disorientation for them/us methodologically by mobilizing translation problems in his own translingual discourse, including not only the "culture bumps" (allusions) that Leppihalme (1997) studies, and the full range of other cultural invocatures (Robinson 2003), such as jokes, idioms, metaphors, and registers; but also, as I'll show in this section, syntactic divergences that run seismic lines of force through reference to the extra-semiotic realm.

We might tentatively fractalize the call for a translationalized argumentative model into a gradated scale of possible implementations, from a weak to a strong extreme. The weak extreme might consist in the admonition that Lotman discuss his (few) non-Russian illustrations in problematic interchanges with their Russian translations, and his (many) Russian illustrations in problematic interchanges with their (say, English) translations. This would roughly correspond to the method I use in this paper. 
But the strong extreme, I suggest, would be even more interesting. In it Lotman, or any translational semiotician following Lotman's model, would present not just his illustrations but her own argumentative text as well in translation-preferably problematic translationand comment on its translational blockages and tensions, and let that argument be constantly vulnerable to dissipative derailment in and through the translational commentary. Argumentative translinguality as a dissipative system.

But again, as the descriptors "fractal" and "scalar gradations" suggest, these "extremes" would not constitute a binary logic but another dissipative system of unpredictable level-jumps (explosive emergences), in which a desperate sinking into argumentative entanglement, with each new translational mobilization only seeming to muddle things more frustratingly, might suddenly emerge into elegant clarity; or, more often, perhaps, in which a calmly and stably "transcendental" statement of abstract universal truth might instantly be undermined by its exemplification through practical translation, and that undermining might lead to new insights, new formulations.

One might even imagine the linguistic principle that would enable the attainment of that strong extreme's fullest complexity along lines like these:

Один из основных вопросов, которые ставит текст, может быть описан следующим образом. В ряде европейскихязыков имеется категория артиклей, разделяющая имена на погруженные в очерченный мир вещей, лично знакомых, интимных по отношению к говорящему, и предметов отвлеченного, общего мира, отраженного в национальном языке. Отсутствие в русском языке артиклей не означает отсутствия данной категории. Она только выражается другими средствами. (Lotman 103)

One of the fundamental questions posed by the text can be outlined as follows. In a number of European languages there is the category of articles which group nouns into those which are immersed in the restricted world of objects, personally familiar and intimately related to the speaker, and the designation of objects which are abstract generalisations reflected in the national language. The absence of articles in the Russian language does not indicate the absence of a given category. The latter is simply expressed by other means. (Clark 117)

This is another binary logic, obviously; and Lotman's point would have been much easier to illustrate in a bilingual or translingual text-say, Lotman printing his Russian text face-à-face with a translation into a European language that does have articles, like English. Still, a hint at the kinds of insights that a translingual text could generate can also be quite handily gleaned through a stereoscopic reading of his Russian original and Wilma Clark's English translation. For example:

Действительно, салон княгини не имел политического характера, но остров, где создавалась искусственная атмосфера культа прекрасного, приобретал на фоне николаевских порядков неожиданно совсем не нейтральный характер. (91-92; emphasis added) 
In reality, the salon of princess did not have a political nature, however, it was an island wherein an artificial atmosphere of the culture of beauty and fine arts was generated and one which acquired, against the background of Nicholas's regime, an unexpected meaning that was in no way neutral. (101; emphasis added)

In a strictly morphological sense, "салон княгини" is "salon of princess"-no definite article before either noun-but Clark only gives us half of that literalism, specifying a single salon but not a single princess. The beautiful "остров”/“island” was the salon-of-princess. As Clark understands the phrase, "the salon" is in Lotman's terms "immersed in the restricted world of objects, personally familiar and intimately related to the speaker," while "princess" belongs to that group of "objects which are abstract generalisations reflected in the national language." It's not a specific princess, say, the Princess Volkonskaya; it's the abstract quality of princessness. Since Lotman is writing about the Princess Volkonskaya's salon, of course, this would again be normally considered a translation error; but in the context of his abstract generalizations about the semiosphere, it also draws salutary attention to the slippage between these two semiotizations of "princess(ness)," in Russian and English. In Russian, the "restricted world of objects [that is] personally familiar and intimately related to the speaker" is not specially marked, and must be inferred-but because it remains implicit, it may also be phenomenologically blurred, by Russian individuals or communities, into significant overlap with the category of "abstract generalisations reflected in the national language."

Look back to the first page in this article for a moment, to the end of the first paragraph in section 1, where I write of the "irreducible conflict that is improperly reduced in most discussions of text." Isn't "text" there used very much as "princess" is used in Clark's translation? Wouldn't the "abstract generalisation reflected in the national language" there properly be "textuality"? Wouldn't "text" normally fall into the "restricted world of objects [that is] personally familiar and intimately related to the speaker," and so take the definite article, "the text"? This is a syntactic issue, obviously, but the problems it raises deal with reference to realia: what is the object to which "text(uality)" there refers? Is it a single text? Is it an abstraction that includes all possible texts? Or is it an abstraction that is situationally objectified in and through discussions of specific texts? (Or perhaps all three at once?) The fact is, though grammatical purists work very hard to convince themselves that they can know the answer to any such question, and that anyone who deviates from the formal requirements set by their epistemological certainty therefore commits an offence, they can't know. Lotman insists throughout that art is created out of that uncertainty-out of the unpredictability of explosions-and "ordinary" language, which doesn't generate that uncertainty, is “принципиально противоположна искусству” (107)/“fundamentally opposed to art” (Clark 121). I would take that insistence a step further and say that all language, all communication, all culture is created out of that uncertainty. Art is just an extreme escalation of the phenomenological experience of such uncertainties.

One more complication: in the interpretive community (Fish 1980: 147-74) in which I was trained-literary scholars and critical theorists- "text" is used as a noncountable abstraction; but 
among non-literary scholars and non-theorists, it tends to be used countably. How should I use it here? If I assume that all my readers will be literary scholars and critical theorists, I (think I) am safe using it noncountably; but what will readers from outside those groups think? Perhaps I should play it safe and edit "text" to "textuality"? (I did that, in fact, as soon as I noticed the problem; but then undid the edit, in order to comment on the problem here.)

One last remark on the salon-of-princess: I don't know of any interpretive communities for whom "princess" is a noncountable abstraction; but that doesn't mean such communities don't exist. It also doesn't mean that a poet won't tomorrow use it that way, "explosively," emergently-or, a fortiori, that Clark wasn't using it that way in translating Lotman's “салон княгини." Нere's another example:

Подобная легенда была обязательным украшением атмосферы салона. (93; emphasis added)

Such a legend was a required embellishment to the atmosphere of salon. (103; emphasis added)

There, "atmosphere-of-salon" seems less strange in English than "salon-of-princess" did in the previous passage, suggesting that the abstract quality of "salonness" is more commonly recognized in English than the abstract quality of "princessness." In this passage, in fact, one can imagine not only two binary readings of "атмосфера салона" as "the atmosphere of [the one specific] salon [about which we are speaking]" or "the atmosphere of salon[ness in general]," but, again, a sliding scale between the two binary poles, with different degrees of specificity and generality mixed. (For example, it's salonness in general, but tinged in the imagination with the more specific qualities of Princess Volkonskaya's salon.)

The resulting indeterminacy would mean that just listing two corrective translations wouldn't solve the problem:

[Ø] Such a legend was a required embellishment for the atmosphere of salons in general.

[1] A legend of this sort became an essential embellishment of the Volkonskaya salon's atmosphere.

Those corrective renditions mark off the binary extremes of $(\varnothing)$ "objects which are abstract generalisations reflected in the national language" and (1) "the restricted world of objects, personally familiar and intimately related to the speaker," but do not even begin exploratorily to map the middle ground between those extremes. And even if we do aim for that middle, as in the fractal option $(1 / n)$

[1/n] A legend of this sort became an essential embellishment of the salon's atmosphere.

-that still leaves us with three different translations, a shifting multiplicity in place of the stable unitary clarity that is standardly expected of published translations. And, of course, since 
that shifting multiplicity is precisely what Lotman is theorizing as the translational nature of the semiosphere, the translation problems raised by Clark's “erroneous" rendition are exactly germane to Lotman's point. Clark elsewhere pushes definiteness in the opposite direction:

\begin{abstract}
В опошленном бытовом поведении это выражалось как стремление завоевать право на мужскую прическу, мужские профессии, мужские жесты и манеру речи. (96; emphasis added)
\end{abstract}

In the vulgar behaviour of the everyday this was expressed in the right to sport a man's hair-do, to take up a male profession, male gestures and manners of the speech. (108; emphasis added)

Here Clark adds "the" to the abstract noun "speech," seemingly implying that the subject of Lotman's discussion here, Georges Sand, is giving a countable speech, an oration, which is somehow mannered. Idiomatically, of course, we say "manners of speech," or rather "mannerisms of speech," because in this generalized sense, "speech" is a noncountable abstraction. The disruptive effect of the definite article here is as dizzying as the lack of a definite article before the second noun in "the salon of princess" and "the atmosphere of salon," because idiomatized speech (not "the" idiomatized speech) is what I call "icotized," rendered normatively plausible and so (precariously) stabilized through communal vetting. More on icosis in section 3.

Before we move on to that concluding topic, however, let us pause to consider another syntactic divergence between Russian and English in their mappings of cultural/semiotic logic onto extracultural/extra-semiotic reality, which, as I noted above, often leads to translation problems that are derogated as "translation errors": namely, syntax identifying the scope of phenomena covered by a specific description. In English, the syntactic structures I'm interested in here are traditionally divided binarily into restrictive and non-restrictive modifiers, whether they appear as noun phrases containing post-positional adjectival phrases ("politicians using social media"-always restrictive) or as subordinate clauses:

Politicians who use social media are dangerous. (restrictive: Only those politicians who use social media are dangerous)

Politicians, who use social media, are dangerous. (non-restrictive: All politicians use social media and all politicians are dangerous)

This distinction is even clearer when it is marked not only with punctuation but with different relative pronouns (restrictive "that" vs. non-restrictive "which"):

The problems that have been proliferating lately require immediate attention. (restrictive: Only those problems that have been proliferating lately require immediate attention) 
The problems, which have been proliferating lately, require immediate attention. (non-restrictive: All of the problems that we've been discussing have been proliferating lately, and all of them require immediate attention)

Things work differently in Russian. When it uses relative pronouns and subordinate clauses, it does not mark the distinction between restrictive and non-restrictive usage at all:

В процессах, которые совершаются при активном участии механизмов самосознания, это переломный момент. (Lotman 25: a restrictive subordinate clause, about only those processes that are completed through active participation, that is marked syntactically like a non-restrictive clause in English)

Случаи, о которых мы будем далее говорить, имеют иной характер. (Lotman 45: a restrictive subordinate clause, about only those cases about which we will be speaking, that is marked syntactically like a nonrestrictive clause in English)

Both languages, as I say, also use embedded post-positional adjectival clauses to serve a similar restrictive syntactic function; the difference here is that in English we don't separate the postpositional adverbial phrases off from the noun they modify with commas, except (as in the first example below) when a parenthetical clause is inserted:

В пространстве, лежащем за пределами нормы (на норме основанном и норму нарушающем), мы сталкиваемся с целой гаммой возможностей. (73)

In the space (lying) beyond the limits of the norm, based on and disrupting the norm, we come across an entire range of possibilities.

Однако необходимо подчеркнуть, что граница, отделяющая замкнутый мир семиозиса от внесемиотической реальности, проницаема. (102)

However, it must be emphasized that the boundary separating the closed world of semiosis from extrasemiotic reality is permeable.

We could also translate those two structures with restrictive subordinate clauses: "in the space that lies beyond the limits of the norm we come across ...," "the boundary that separates the closed world from extra-semiotic reality is permeable."

Wilma Clark's apparent ignorance of these differences frequently propels her English syntax into what to the untrained eye appears to be a mangling of the Russian original; but I submit that it is precisely in this kind of "mangling," or disruptive divergence, that Lotman's theoretical insistence comes to a head-or should do-on the necessity of thinking dissipatively, through 
translation, about the semiosphere and its energy-exchanges with the extra-semiotic realm. All of the passages below are restrictive, but because the adjectival phrase in each is-standardly, "correctly"-marked off in Russian with commas, Clark follows suit, and in so doing makes them non-restrictive in English:

В процессах, которые совершаются при активном участии механизмов самосознания, это переломный момент. (25)

In processes, which are accomplished through active participation of the mechanisms of self-consciousness, this is the critical moment. (Clark 16: processes are a distinct phylum, like fungi, and all members of that phylum are accomplished in that specific way)

Случаи, о которых мы будем далее говорить, имеют иной характер. (45)

The cases, which we will now consider, have quite another character. (Clark 43: all of the cases have that other character, and the fact that we will now be considering them is parenthetical and therefore incidental)

В пространстве, лежащем за пределами нормы (на норме основанном и норму нарушающем), мы сталкиваемся с целой гаммой возможностей. (73)

In the space, which lies beyond the limits of the norm (which is based on the norm and which disrupts it), we encounter a whole range of possibilities. (Clark 78: "the space" is a single definite thing that [a] we already know about, [b] always and inevitably lies beyond the limits of the norm, and [c] is always based on the norm and disrupts it)

Трудно найти другие стихи, в которых женственность обливалась таким презрением; (99)

It is difficult to find other verses, in which femininity was doused by such contempt; (Clark 111: it's hard to find any kind of verses, anywhere in the world, but wherever one does find them, in every single verse femininity was "doused by" [or saturated in] such contempt)

Однако необходимо подчеркнуть, что граница, отделяющая замкнутый мир семиозиса от внесемиотической реальности, проницаема. (102)

However, it is necessary to emphasise the fact that the boundary, which separated the closed world of semiosis from extra-semiotic reality, is permeable. (Clark 115: there is only one boundary, and it is permeable, period; the fact that in the past it also once separated semiosis from extra-semiosis is an optional parenthetical addition that could be omitted without changing the meaning of the sentence) 
It is, I suggest, precisely because Clark so frequently shifts Lotman's restrictive clauses into nonrestrictive syntactic environments, so that his attempts to limit the scope of reality he describes are ballooned out into potentially universal claims, that her translation makes such a powerful contribution to Lotman's theory. This is especially true of that last example, where Lotman's account of a shifting permeable boundary between semiosis and extra-semiosis-arguably his overriding concern in theorizing the semiosphere-is chopped up into smaller bite-sized pieces that can be safely cordoned off into separate enclosures marked with commas, and the most important part of the claim, that this is a boundary specifically between semiosis and extra-semiosis, becomes parenthetical and thus dispensable.

But there is also the example that I mentioned briefly in section 1 (p.13), where she translates "сама неразрешимая фантастика" (lit. "itself unresolvable fantasy") as "the fantastic itself that is insoluble." There, since Lotman seems to be saying that all fantasy is irresolvable-fantasy itselfthe "natural" or "idiomatic" way of saying that in English would be "the fantastic itself, which is unresolvable." But who is to say that Lotman does intend the unresolvability of all fantasy? His sentence could easily be read the other way as well, to mean "that type of fantasy that is insoluble"and that is how Clark's syntax suggests she read it, or how her "error" (if we want to be nasty about it) forces us to read it.

\section{Icosis}

One final interesting question that this discussion raises has to do with this "nastiness"- or rather, to put that more neutrally, the strong conviction we often have that a certain way of saying or writing something is right, or wrong, and our incredulity that any other native speaker of the language should not feel the same conviction. Whence this apparent certainty about correctness, and this anxiety-produced animus against incorrectness? Why is error analysis not only an everpresent temptation, but in almost every sense the norm, in translation criticism?

For example, thinking about the two competing interpretations of Lotman's noun phrase “сама неразрешимая фантастика"- "the fantastic itself, which is unresolvable," and "that type of fantasy that is insoluble"-I feel a very strong conviction that the former is obviously and indeed overwhelmingly correct, and the latter is just plain absurd. I believe that if he had meant to say "that type of fantasy that is insoluble," he would have written the sentence differently: "этот неразрешимый тип фантастики," or the like.

So my question in this final section is: what force organizes a language in this viscerally compelling way, so that I can have this sort of rock-solid belief that I am right to read a sentence in one way rather than in another? How exactly can a "translation error," or any phrasing in any text, "force" us to read it in a certain way? What is it about a "language," or about the way a community structures a language, that makes it seem intuitively correct to us to say that "in English we distinguish syntactically between restrictive and non-restrictive modifiers, whereas Russian does not mark the distinction between restrictive and non-restrictive usage syntactically at all"? In the introduction I described the semiosphere's management of its shifting boundary with the extra- 
semiotic as "(self-)organized(/-ing)" and "(self-)structuring": how does that work? What kind of agency does the semiosphere have to initiate and carry out such organizing/structuring actions? And, at the highest level of Lotman's translational semiotics, what exactly is going on when “моменты взрыва ... созда[ют] как бы окна в[о внешнем] семиотическом пласте”/“moments of explosion ... create a kind of window in the [outer] semiotic layer," creating a "прорыв[] в запредельное пространство"/“breakthrough into the space beyond the limits” (Lotman 30, Clark 24)? What exactly are these layers, spaces, limits, windows, and breakthroughs? They are, obviously, architectural metaphors for some sort of event-but what? Is it a phenomenology? (Do we "experience" it in some more or less conscious way?) Is it a preconscious neural event, managed by the autonomic nervous system? Is it a preternatural event?

Lotman does not ask these questions-though arguably he should have. If his two-language theory of the semiosphere means that the ideal vantage-point for any semeiotic is a transsemeiotic, an engagement with the destabilizing effects of translations between the certainties of two different semiospheres, surely one possible risk factor in that engagement would be the impulse to reestablish certainty between two different semiospheres, through translational error analysis. And if Lotman's desired outcome is the destabilization of such certainties in both realms, both within individual semiospheres and between semiospheres, surely it is not enough simply to invoke "translation" as a kind of cure-all. Translation may indeed destabilize certainties within individual semiospheres, but it doesn't always do even that (think of the historical use of grammar translation to teach single-language grammar); and every translator has felt the normative pressure to stabilize transfer patterns between his or her source and target languages (hence the historical tendency for translation criticism to gravitate to error analysis).

It would seem to me, therefore, that some understanding of the neurocultural forces that seem to compel us to impose stability in both realms must be crucial for the Lotmanian transsemiospheric project. And for that I suggest that we turn to the work of Mikhail Bakhtin (1895-1975), who was a powerful influence on Lotman's thinking-and has foundationally shaped my own as well. (For me, the foundational Bakhtin text has been Слово в романе [1934-1935/1975], translated by Caryl Emerson and Michael Holquist [1981] as Discourse in the Novel.) Bakhtin doesn't really answer the questions about how a language is so effectively organized as to feel stable and real either, but he outlines a series of principles on which an answer can begin to be built.

The first principle is that “Единый язык не дан, а, в сущности, всегда задан” (Bakhtin 83)/“А unitary language is not something given [дан] but is always in essence posited [задан]" (Emerson and Holquist 270). Another way of putting that is that the unification of language is a communal task or goal (задача): the community that speaks a language works to unify it, because a more or less unified language makes communication possible; but that task, once posited, is never completed. It is ongoing.

The second principle is that a unitary language is what Ilya Prigogine (1973) would later call a dissipative system, or what Bakhtin called "разноречие," and Emerson and Holquist translate as "heteroglossia." Heteroglossia is sometimes understood as the creative impulse toward disorder 
that undermines a unitary language, but as Holquist (1990: 428) shows, heteroglossia for Bakhtin is actually "as close a conceptualization as possible of that locus where centripetal and centrifugal forces collide; as such, it is that which a systematic linguistics must suppress." The two terms in Lotman's title, "culture" and "explosion," refer loosely to these same two impulses that Bakhtin calls centripetal and centrifugal, and both are channels of heteroglossia. As Holquist adds, "all utterances are heteroglot in that they are functions of a matrix of forces practically impossible to recoup, and therefore impossible to resolve." Heteroglossia is "chaos" not as disorder, but as the tension between order and disorder: "that locus where centripetal and centrifugal forces collide." A precarious new order can emerge, "explode," out of apparent chaos; but a disruptive new chaos can also "explode" out of apparent stability.

The third principle is that heteroglossia is channeled through bodies-specifically, through the tonalization of embodied voices, and, more specifically still, through the multiple tonalizations that are stored and carried in individual embodied voices. We internalize the tonalizations (which Bakhtin calls "accents" and identifies as the carriers of "attitudes") that we hear and feel in the words spoken to and around us; and in making them our own, we blend them with the existing mix, so that every word we hear and speak socializes us further, makes us more corporeally, and thus also more attitudinally, part of the community. The fact that all of us want and need to be able to understand others and to be understood ourselves pushes us to conform our usages to those we hear others around us using-to tonalize or "dialogize" our voices convergently (centripetally) - but the fact that we occupy different bodies, and can never experience anything in the same way or from the same place, inflects all of our tonal/vocal/dialogical conformism with difference, with divergence (centrifugality), as well. Our best efforts to conform to communal norms-what Bakhtin calls unitary language, what Prigogine calls system, what Lotman calls culture-sometimes, inevitably, but unpredictably, slip and fail, and "explode" centrifugally in what Prigogine calls symmetry-breaking events.

What this Bakhtinian model still cannot explain, however, is just how language is stabilized "centripetally," and how that stabilization can be so reificatory as to make us believe that it, and everything it touches, is real. He does note that this happens:

Но в то же время он реален как сила, преодолевающая это разноречие, ставящая ему определенные границы, обеспечивающая некоторый максимум взаимного понимания и кристаллизующаяся в реальном, хотя и относительном единстве господствующего разговорного (бытового) и литературного языка, «правильного языка». (84)

But at the same time it makes its real presence felt as a force for overcoming this heteroglossia, imposing specific limits to it, guaranteeing a certain maximum of mutual understanding and crystalizing into a real, although still relative, unity-the unity of the reigning conversational (everyday) and literary language, "correct language." (270) 
But he doesn't attempt to explain how it happens-how it is possible for language, fleeting sounds and fading marks on the page, to be "реален как сила": real as a force.

My term for that real-making force-a cultural or communal force-is "icosis," which I derive from Aristotle's insight in the Rhetoric that, given a choice between a true story that is implausible and a plausible (eikos) story that is untrue, we will almost always choose the plausible story, regardless of its "actual" truth or falsehood, because plausibility (ta eikota) is a sign that the story has been vetted by the community. ${ }^{3}$ But Aristotle does not set himself the task of explaining how this cultural phenomenon is possible either.

My theory of icosis is built on the foundation of my somatic theory, which in turn rests on Antonio R. Damasio's somatic-marker hypothesis (1994). That is the theory, repeatedly tested in Damasio's neurology lab and confirmed by other cognitive neuroscientists, ${ }^{4}$ that the autonomic nervous system sends us little "reminders" of what we have learned experientially, in the form of "somatic responses": sweaty palms, butterflies in the stomach, a constriction in the throat or chest, or, on the positive side, a spreading warmth and sense of well-being. These somatic markers, as he calls them, do not do our thinking for us; but they do guide our thinking, by narrowing our options and signaling to us which course of action would best suit the experiential lessons we've learned in the past.

In his later work, Damasio (2003) incorporates the findings of a part of his team to the effect that the mirror-neuron system makes somatic markers shareable: if you feel strongly disinclined to undertake some action, I can not only be persuaded by your words, but swayed unconsciously by your body language, which my autonomic nervous system reads as a playbook for the simulation of your internal body states. This dyadic mimicry, which I call somatic mimesis, is the basis for empathy ${ }^{5}$ and, ultimately, all ethical feeling and growth. It is also the basis for what Bakhtin calls the "internal dialogism of the word": the sharing (internalization/externalization) of vocal tonalizations with the person you're talking to.

The third level of somatic theory is what I call the somatic exchange: the circulation, or "reticulation," of somatic mimeses almost simultaneously throughout an entire group, so that you come to feel almost-almost-like a single collective body. This would explain both the centripetal impulse that Bakhtin theorizes, to conform your tonalizations to the group, and thus to unify language, and also, because we occupy different bodies, the centrifugal deviations-and often the collectively amplified deviations-from shared normative feelings that cause disruptions or "explosions" within stabilized structures.

Icosis, then, is the fourth level, built on top of the lower three. It emerges out of the mimetic circulation of somatic "plausibilization" through the somatic exchange, so that the resulting attitudes

3 I first formulated a somatic theory of translation in Robinson (1991); more recent explorations and retheorizations include Robinson $(2011,2015)$. Icotic theory began to emerge as an extension of somatic theory in early drafts (from about 2009) of what eventually became Robinson (2016a); see also Robinson (2013c, 2016b, 2016c, 2017a, 2017b, 2017c). 4 See e.g. LeDoux (1999: 293; 2003: 306; 2015: 134-38, 224).

5 See Robinson (2013b: 150-54) for a review of the social neuroscientific research on empathy. 
and opinions come to seem not only right but real. This is why we tend to believe a plausible-butuntrue story over a true-but-implausible story: communally vetted plausibility feels real, "реален как сила"/"real as a force." It is also why it often seems to us that a language we speak fluently has stable structures, and even, as Walter Benjamin says, anthropomorphic "intentions": English wants us to distinguish between noncountable abstract nouns (no article) and countable nouns for specific items (definite or indefinite article), and Russian doesn't care about such distinctions. English wants us to distinguish syntactically between restrictive and nonrestrictive modifiers with "that" and no commas for the former and "which" and commas for the latter, and Russian would rather use “который" and commas for both. Because we can feel the shaping force languages (and, Lotman would add, semiospheres) have on our usage, they feel phenomenologically alive, animate, agentive.

The icotic agency that organizes and structures semiosis, in this model, is not "the sign" or "the language," but the human groups that create and maintain the semiosphere. Because icosis is mostly managed unconsciously, by our autonomic nervous systems, and because it is managed collectively, without executive control by single individuals, we mostly don't notice "our" organizing/structuring/shaping hand in the process: to the extent that we notice icotic semiosis at all, it seems to happen all on its own, as if controlled by some preternatural force. But that is the phenomenology: that is how things feel to us. At what we might call the subphenomenological level of our linked mirror-neuron systems, we do it.

This is the social neuroscience of hermeneutics, and it should go without saying that it works in both same-language and two-language (interlingual/transsemiotic) engagements (see Robinson 2017d: Essay 3 for discussion). Just as icosis plausibilizes (normativizes, stabilizes) certain speech patterns as "correct" as guidance for speakers within individual languages, so too does it plausibilize (normativize, stabilize) certain transfer patterns as "correct" as guidance for translators within specific language pairs. So strong is this "centripetal" impulse in our cognitive and affective processing of all (trans)semiosis, flagrantly disruptive obstacles to it must be raised at all levels if one hopes to achieve the kind of destabilization imagined in Lotman's two-languages semeiotic. Again, Lotman's assumptions to the contrary, "translation” cannot serve as a necessary and sufficient disruption to semiospheric stabilities. There are transsemiospheric stabilities as well.

But then how does the semiotic energy-exchange at the boundary between the semiosphere and the extra-semiotic work? In Lotman's formulation “Их взаимная непереводимость (или ограниченная переводимость) является источником адекватности внеязыкового объекта его отражению в мире языков” (Lotman 13)/“Their mutual untranslatability (or limited translatability) represents a source of adjustment of the extra-lingual object in its reflection in the world of languages" (Clark 2), what exactly is the “адекватность внеязыкового объекта"/“adjustment of the extra-lingual object"?6 Or, more fully, what is the "проницаемость"/"permeability"

6 Let me mention in passing that here is another example of transsemiospheric dissonance that would have profited from a bilingual presentation: “адекватность внеязыкового объекта" would normally be translated not dynamically as "adjustment of the extra-lingual object" but more statically as "adequacy of the extralingual object." In trans- 
of the “граница, отделяющая замкнутый мир семиозиса от внесемиотической реальности”/“boundary separating the closed world of semiosis from extra-semiotic reality”?

Однако необходимо подчеркнуть, что граница, отделяющая замкнутый мир семиозиса от внесемиотической реальности, проницаема. Она постоянно пересекается вторжениями из внесемиотической сферы, которые, врываясь, вносят с собой динамику, трансформируют само пространство, хотя одно-временно сами трансформируются по его законам. Одновременно семиотическое пространство постоянно выбрасывает из себя целые пласты культуры. Они образуют слои отложений за пределами культуры и ждут своего часа, чтобы вновь ворваться в нее настолько забытыми, чтобы восприниматься как новые. Обмен с внесемиотической сферой образует неисчерпаемый резервуар динамики.

Это «вечное движение» не может быть исчерпано - оно не поддается законам энтропии, поскольку постоянно воссоздает свое разнообразие, питаемое незамкнутостью системы. (Lotman 101-2)

However, it is necessary to emphasise the fact that the boundary separating the closed world of semiosis from extra-semiotic reality is permeable. It is constantly transgressed via intrusions from the extrasemiotic sphere which, when bursting in, introduce a new dynamic, transforming the bounded space and simultaneously transforming themselves according to its laws. At the same time, semiotic space constantly ejects all the layers of culture from itself. The latter form layers of deposits beyond the limits of culture and await their time to re-enter the closed space, by which time they are so 'forgotten' as to be conceived of as new. Such exchanges with the extra-semiotic sphere create an inexhaustible reservoir of dynamic reserves. This "perpetual motion" cannot be exhausted-it does not yield to the laws of entropy, since its variability is constantly being fed by the permeability of the system. (Clark 115; translation modified)

My icotic model would suggest that the "семиотическое пространство"/"semiotic space" is "незамкнутое"/“unclosed" and "проницаемое"/"permeable" because icosis is the constant communal (re)plausibilizing of all the relevant evidence available to the somatic exchange-and while that icotic action is designed to suppress extra-semiotic or extra-icotic “вторжении”/“intrusions” as irrelevant, it cannot possibly suppress them all. "Внеязыковые объекты”/“Extra-lingual objects” press upon icosis from all sides, demanding recognition, lining up for communal "vetting" as plausible.

That is a personification, of course, pointing implicitly at the hermeneutic panic members of the community feel whenever something happens that makes no "common" (communally vetted, plausibilized, icotized) sense. It feels to us as if the objects themselves are demanding recognition; icotic theory suggests that it is the community's nervousness about extra-icotic reality that,

lating “адекватность”/adequacy as adjustment, Clark is adding a corrective impulse to the equation, an attempt to make the extralingual object adequate. 
because that nervousness is mostly unconscious, is a human phenomenology projected onto the objects themselves.

Lotman too indulges this sort of personification in "Она постоянно пересекается вторжениями из внесемиотической сферы, которые, врываясь, вносят с собой динамику, трансформируют само пространство, хотя одно-временно сами трансформируются по его законам"/“It is constantly transgressed via intrusions from the extra-semiotic sphere which, when bursting in, introduce a new dynamic, transforming the bounded space and simultaneously transforming themselves according to its laws." Icotic theory, as I first argued in Schleiermacher's Icoses (2013c: ch. 6), would suggest that the hermeneutic agency behind the transformations belongs not to the intrusions but to the community constantly working to maintain a plausible and more or less coherent model of reality. That model would be the "законы"/ "laws" of which Lotman writesaccurately enough, in a phenomenological sense, for, while the icotic coherence imposed by the community on the evidence available to it is never literally legislated, and lacks the kind of systematic regularity that we normally (though perhaps inaccurately) associate with laws, we do typically think of that coherence as lawlike (the laws of nature, etc.).

The one part of Lotman's description there before which I confess explanatory helplessness is his notion of a "circulation" of “целые пласты культуры"/“whole strata of culture" back and forth between the semiosphere and the extra-semiotic sphere. I cannot imagine how these "strata" or "layers" might be stored as “слои отложений за пределами культуры”/“deposits beyond the limits of culture," where they “ждут своего часа, чтобы вновь ворваться в нее настолько забытыми, чтобы восприниматься как новые"/“await their time to re-enter the closed space, by which time they are so 'forgotten' as to be conceived of as new." Icotic theory has no explanation for the ejection and storage of cultural material "beyond the limits of culture," let alone for the personification of those "deposits ... await[ing] their time to re-enter the closed space." It's an intriguing idea, but I can't for the life of me figure out how it might work. I hope someone else will be able to explain it to me.

\section{Conclusion}

I have been arguing for an extension of Lotman's exciting theory of the translational semiosphere beyond the monolingual presentation of it that one finds in his work-an extension into the realm of stereoscopic reading strategies, at the very least, but also, potentially, into the realm of translingual writing strategies. The problem with that latter, of course, is that translingual academic argumentation is not a commonly accepted academic genre, which would make it difficult (but not impossible) to publish.

My very first monograph effort in the Translation Studies field, in fact, was an experiment of this sort: a translingual book-length study printed face-à-face, Finnish on the verso, English on the recto, titled "Kääntämisen kääntöpiirit/The Tropics of Translation." I created it in 1985-1986, sort of on the model of Jacques Derrida's Spurs: Nietzsche's Styles/Eperons: Les Styles de Nietzsche (1981) - except that the English side of Derrida's book was translated by Barbara Harlow, and I 
both wrote the English on the recto and translated it into Finnish for the verso. My idea was that translating the text into Finnish would require that I reflect not only on the changes that the Finnish readership would push me to make in the text, but on the very nature of translation.

And it worked, quite well, I thought: I would find myself deviating quite sharply from the English text, for several pages, and then start trying to bring the Finnish text back into alignment with the English original, so that five to ten pages on I could again proceed paragraph by paragraph across the centerfold. The only problem was that, because the non-English language was not French but Finnish, I could really only hope to publish it with a Finnish university press, and the Finnish university presses to whom I proposed it proved to be pretty conservative, and uninterested in experimental academic discourse. So I cannibalized the book monolingually as The Translator's Turn (1991) — and, as a result, am completely sympathetic with the complaint that the translingual writing model I'm suggesting here would not be attractive to publishers.

However, while the workaround I've been mining in this article-staging that translational/ translingual engagement through a stereoscopic reading of the two texts published separately, Lotman's Russian original and Clark's English translation-does work well enough for illustrational purposes, I submit that it is not in the end adequate to Lotman's own theoretical purposes. He does illustrate his theory of "culture and explosion" with copious examples from literary history; but without this translational intervention from Wilma Clark, the specifically translational moment in his theory remains abstract, and so "reflected in the national language" (Russian) without becoming "personally familiar and intimately related to the speaker."

One might want to protest that the kind of stereoscopic reading strategy for which I am advocating would only make Lotman's translational theory of the semiosphere "personally familiar and intimately related to the bilingual speaker," perhaps even the bilingual speaker who is also a practicing translator; but according to Lotman himself, this kind of bi- or multi- or translingualism is an ineradicable part of all semiosis.

The problem, of course, is that this enhanced kind of translational reading of Lotman's translational theory of the semiosphere requires not only a knowledge of contrastive syntax between Russian and English, but a willingness to tease out of specific cases-the (kinds of) cases that we've been considering, restrictively-the nuanced implications that they might have for translational semiotics. The translational/translingual writing strategy for which I am advocating requires of the reader more translational/translingual skills and more energetic critical thinking than is typically expected of academic readers, and that may make it difficult to implement in practice.

But if the theory seems to demand it, as Lotman's seems undeniably to do, isn't it worth a try?

\section{References}

Bakhtin, Mikhail. 1934-35/1975. Slovo v romane ("Word in the Novel"). In Voprosy literatury i estetiki ("Questions of Literature and Aesthetics"), 72-233. Moscow: Khudozhestvennaya Literatura. 
Benjamin, Walter. 1923/1972. “Die Aufgabe des Übersetzers.” In Tillman Rexroth, ed., Kleine Prosa, Baudelaire-Übertragungen, 9-21. Vol. 4, Part 1 of Walter Benjamin, Gesammelte Schriften (“Collected Writings"). Frankfurt am Main: Suhrkamp.

Clark, Wilma, trans. 2005. Juri Lotman, “On the Semiosphere.” Translation of Lotman 1984. Sign Systems Studies 33.1: 205-29.

Clark, Wilma, trans. 2009. Juri Lotman, Culture and Explosion. Translation of Lotman 1992/2000. Edited by Marina Grishakova. Berlin and New York: Mouton de Gruyter.

Damasio, Antonio R. 1994. Descartes' Error: Emotion, Reason, and the Human Brain. New York: Putnam.

Damasio, Antonio R. 2003. Looking for Spinoza: Joy, Sorrow, and the Feeling Brain. New York: Harcourt.

Derrida, Jacques. 1981. Spurs: Nietzsche's Styles/Eperons: Les Styles de Nietzsche. Translated by Barbara Harlow. Chicago, IL: University of Chicago Press.

Emerson, Caryl, and Michael Holquist, trans. 1981. Mikhail Bakhtin, Discourse in the Novel. Translation of Bakhtin 1934-35/1975. In Michael Holquist, ed., The Dialogic Imagination: Four Essays, 259-422. Austin: University of Texas Press.

Fish, Stanley. 1980. Is There A Text in This Class? Cambridge, MA: Harvard University Press. Holquist, Michael. 1990. Dialogism: Bakhtin and his World. London and New York: Routledge.

LeDoux, Joseph. 1999. The Emotional Brain: The Mysterious Underpinnings of Emotional Life. London: Phoenix.

LeDoux, Joseph. 2003. Synaptic Self: How Our Brains Become Who We Are. London: Penguin.

LeDoux, Joseph. 2015. Anxious: The Modern Mind in the Age of Anxiety. London: Oneworld.

Leppihalme, Ritva. 1997. Culture Bumps: An Empirical Approach to the Translation of Allusions. Clevedon and Philadelphia: Multilingual Matters.

Lotman, Juri. 1984. "O semiosfere" (On the Semiosphere). Sign Systems Studies 17: 5-23.

Lotman, Juri. 1992/2000. Kul'tura i vzryv. In Lotman 2000: 12-148.

Lotman, Juri. 1996/2000. Vnutri myslyasshikh mirov: Chelovek - Tekst - Semiosfera - Istoriya (Inside the Worlds of Thought: Person-Text-Semiosphere-History). In Lotman 2000: 150-390.

Lotman, Juri. 2000. Semiosfera. Kul'tura i vzryv. Vnutri myslyasshikh mirov. Stat'i. Issledovaniya. Zametki ("The Semiosphere. Culture and Explosion. Universe of the Mind. Articles. Researches. Notes"). St. Petersburg: Iskusstvo-SPB.

Prigogine, Ilya. 1973. "Can Thermodynamics Explain Biological Order?" Impact of Science on Society 23: 159-79.

Rendall, Steven, trans. 1998. Walter Benjamin, “The Translator's Task." TTR: traduction, terminologie, rédaction 10.2: 151-165. Translation of Benjamin 1923/1972.

Robinson, Douglas. 1991. The Translator's Turn. Baltimore and London: Johns Hopkins University Press. 
Robinson, Douglas, trans. 1997/2002. Friedrich Schleiermacher, "On the Different Methods of Translating." Translation of Schleiermacher 1813/2002. In Douglas Robinson, ed., Western Translation Theory From Herodotus to Nietzsche, 225-38. Second edition. Manchester, UK: St. Jerome.

Robinson, Douglas. 2003. Performative Linguistics: Speaking and Translating as Doing Things with Words. London and New York: Routledge.

Robinson, Douglas. 2011. Translation and the Problem of Sway. Amsterdam and Philadelphia: John Benjamins.

Robinson, Douglas. 2013. Schleiermacher's Icoses: Social Ecologies of the Different Methods of Translating. Bucharest: Zeta Books.

Robinson, Douglas. 2015. The Dao of Translation: An East-West Dialogue. London and Singapore: Routledge.

Robinson, Douglas. 2016a. The Deep Ecology of Rhetoric in Mencius and Aristotle. Albany NY: State University of New York Press.

Robinson, Douglas. 2016b. "Pushing-Hands and Periperformativity." In Douglas Robinson, ed., The Pushing Hands of Translation and its Theory: In Memoriam Martha Cheung, 1953-2013, 173-216. London and Singapore: Routledge.

Robinson, Douglas. 2016c. Semiotranslating Peirce. Tartu Semiotics Library 17. Tartu, Estonia: University of Tartu Press.

Robinson, Douglas. 2017a. Aleksis Kivi and/as World Literature. Leiden, the Netherlands, and Boston, MA: Brill.

Robinson, Douglas. 2017b. Critical Translation Studies. London and Singapore: Routledge.

Robinson, Douglas. 2017c. Exorcising Translation: Towards an Intercivilizational Turn. New York: Bloomsbury.

Robinson, Douglas. 2017d. Translationality: Essays in the Translational-Medical Humanities. London and Singapore: Routledge.

Robinson, Douglas. Unpub-a. "Kääntämisen kääntöpiirit/The Tropics of Translation.” Bilingual monograph typescript.

Robinson, Douglas. Unpub-b. "Chaos Linguistics: Language as a Dissipative System (or what Michael S. Gazzaniga's Interpreter Theory Can Tell Us About the Language-Instinct Debate)." Monograph typescript.

Schleiermacher, Friedrich. 1813/2002. "Ueber die verschiedenen Methoden des Übersetzens.” In Martin Rößler, with the assistance of Lars Emersleben, eds., Akademievorträge, 67-93. Part I of Schriften und Entwürfe. Vol. 11 of Kritische Gesamtausgabe. Berlin: BBAW.

Shukman, Ann, trans. 1990. Juri Lotman, Universe of Mind: A Semiotic Theory of Culture. Translation of Lotman 1996/2000. London: Tauris.

\section{Notes}

I'd like to thank Ivan Delazari for checking my reading of the Russian in this article. 